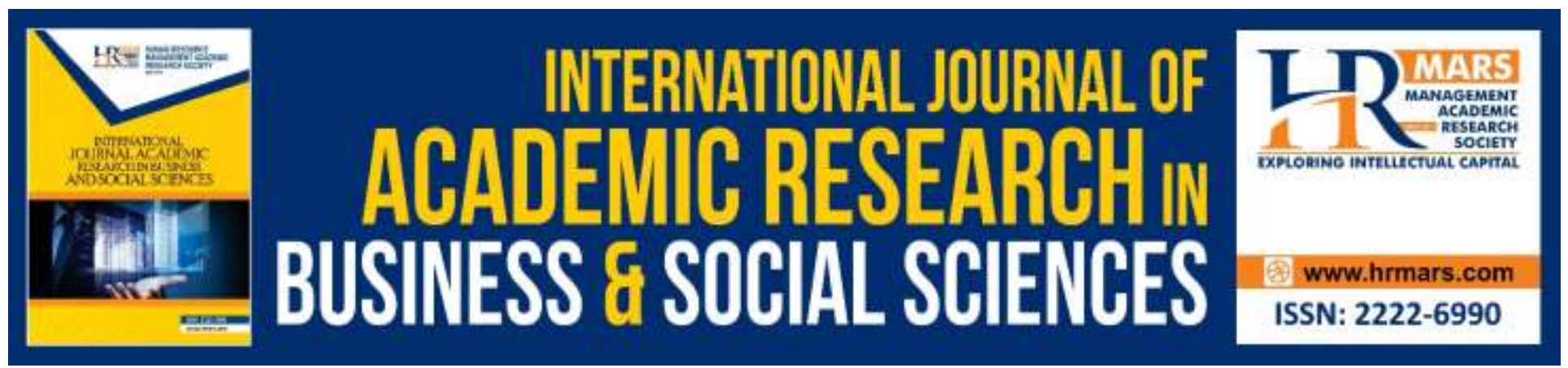

\title{
Crime Lead to War in Ramayana and Hikayat Seri Rama
}

\section{Puganeswari Balakrishnan, Mohamad Luthfi Abdul Rahman and Jelani Harun}

To Link this Article: http://dx.doi.org/10.6007/IJARBSS/v10-i1/6837

DOI:10.6007/IJARBSS/v10-i1/6837

Received: 20 December 2019, Revised: 01 January 2020, Accepted: 12 January 2020

Published Online: 29 January 2020

In-Text Citation: (Balakrishnan et al., 2020)

To Cite this Article: Balakrishnan, P., Rahman, M. L. A., \& Harun, J. (2020). Crime Lead to War in Ramayana and Hikayat Seri Rama. International Journal of Academic Research in Business and Social Sciences, 10(1), 196208.

Copyright: (C) 2020 The Author(s)

Published by Human Resource Management Academic Research Society (www.hrmars.com)

This article is published under the Creative Commons Attribution (CC BY 4.0) license. Anyone may reproduce, distribute, translate and create derivative works of this article (for both commercial and non-commercial purposes), subject to full attribution to the original publication and authors. The full terms of this license may be seen at: http://creativecommons.org/licences/by/4.0/legalcode

Vol. 10, No. 1, 2020, Pg. 196 - 208

http://hrmars.com/index.php/pages/detail/IJARBSS

JOURNAL HOMEPAGE

Full Terms \& Conditions of access and use can be found at http://hrmars.com/index.php/pages/detail/publication-ethics 


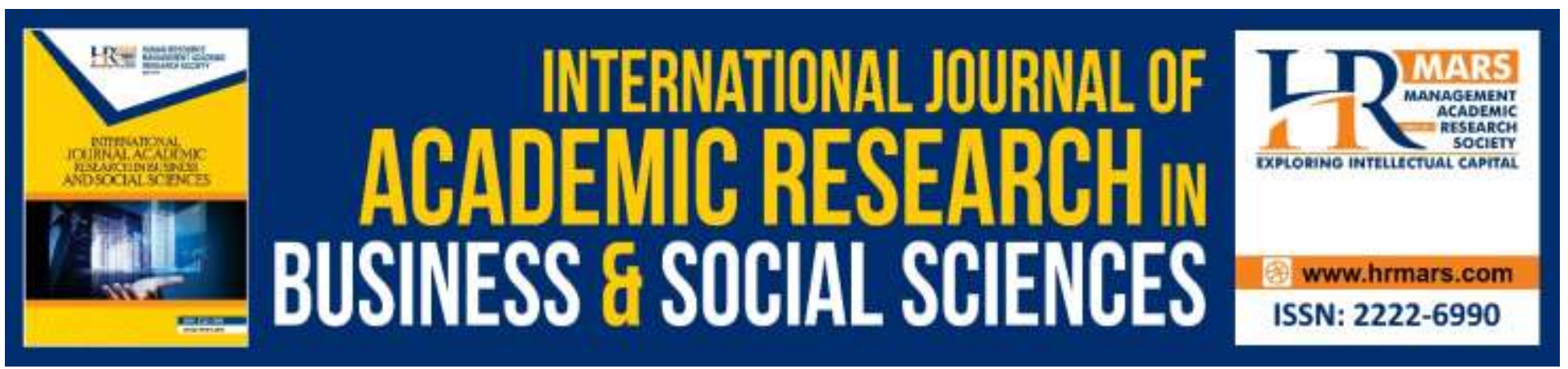

\title{
Crime Lead to War in Ramayana and Hikayat Seri Rama
}

\section{Puganeswari Balakrishnan, Mohamad Luthfi Abdul Rahman and Jelani Harun}

School of Humanities, Universiti Sains Malaysia, 11800, Pulau Pinang, Malaysia.

\begin{abstract}
The Ramayana is an important part of Indian Literature that narrates an epic struggle against the evils of Ravana, and justification of just war. The original text of the Ramayana was written by Valmiki in the 10th century in the writings of Sanskrit that date back to the second century. This work is basically about the battle between Rama with Ravana that culminates in the kidnapping of Sita by Ravana. For this study, an abridged version of Valmiki Ramayana, entitled Sita: An Illustrated Retelling of the Ramayana by Devdutt Pattanaik. This work was published in 2013 by Penguin Publishers located in India. This paper collects various versions of Ramayana published by Devdutt Pattanaik to understand the epic more easily. Meanwhile in alam Melayu, Hikayat Seri Rama oral version recorded by W. E. Maxwell and narrated by Mir Hassan, well known and established Malay storyteller (penglipur lara) in 1885. This hikayat publish in a JSBRAS at 1910. Though Hikayat Seri Rama received influence from Ramayana epic, the storyteller in this hikayat has been modified and has given local colour to showcase the elements of war and strategies. This work will be examined through the concept of just war. The application of sciences like wars, magical, politics, and others who practised in India and Tanah Melayu traditional societies will be given attention and analyzed in this paper. In the end, this study will conclude for all related crime cause the war used by both sides, in accordance with the characteristics of a just war.
\end{abstract}

Keywords: Hikayat Seri Rama, Ramayana, Warfare, Kidnappings, Crime, and Community Norms

\section{Introduction}

Ramayana epic is very popular in India and also in Southeast Asia, most of the people who live in this province radius knows a bit of Rama's story, eldest prince of Ayodhya adventure. Although it sounds hyperbole with this fact Ramayana epic has had a direct or indirect impact on architecture, performing arts, as well as literature adaptive according to the province of the territorial (Singaravelu Sachithanantham, 2004: 1). Valmiki is the author of original version Ramayana, which written in Sanskrit language and also known as Valmiki Ramayana. There are few version of Ramayana had spread out of India with different version according to with the countries such as Hikayat Seri Rama 
versi lisan and Hikayat Seri Rama versi bukan lisan (Malaysia), Reamker (Cambodia), Kakawin Ramayana (Indonesia), Ramakien (Thailand), etc. Furthermore, there is the revised version of Ramayana, including Valmiki Ramayana by Devdutt Pattanaik, Rajendra Tandon and Krishna Dharma has work on revised versions of Ramayana to ease the readers' understanding about the original storyline (Puganeswari Balakrishnan and Rahimah A. Hamid, 2018: 1236).

Furthermore, Ramayana is well known epic from India and war scenario in this epic, propound as dharmayuddha, war fought as a duty (Kaushik Roy, 2012: 30). Valmiki had features crimes that cause war in the Ramayana epic. When Ravana opposed Rama in Lanka, Valmiki has described the atmosphere of war in the epic. It is because, Ravana follows the path of adharma (evil) by committing torture and sin to the muniyar (the sages) and also kidnapped Sita, Rama's wife.

Relatively, the Malay literary selected to compared with Ramayana is Hikayat Seri Rama oral version (Hikayat Seri Rama versi lisan). This text has been copied and romanise by W. E. Maxwell from a storyteller, Mir Hassan who is Malay penglipur lara in 1885. W. E. Maxwell then has published the romanise of Hikayat Seri Rama oral version in JSBRAS at 1910. Despite, Hikayat Seri Rama oral version has influence from Ramayana, but this text becomes a new version through Mir Hassan's creativity and also applied local colourization with Malay identity. Mir Hassan as an author had change name of the character Sita Dewi in Ramayana into Tuan Puteri Sekuntum Bunga Setangkai, while the character of Rama maintained the name of Seri Rama, but become khalifah (ruler) to Tanjung Bunga country. While, Seri Rama and Tuan Puteri Sekuntum Bunga Setangkai have a child named Kera Kecil Imam Tergangga but in Ramayana, Lava and Kusa are children to Rama and Sita.

Research about Ramayana and Hikayat Seri Rama in term of comparative stated that Hikayat Seri Rama is adaption version of Ramayana. It's has been assimilated accordingly to the local society throughout literature, arts and culture. Ding Choo Ming (2018) in The Reworking Indian Epics in the Hands of Javanese and Malay Authors had analyses influences of Ramayana and Mahabharata in Malay and Javanese literary work such as Hikayat Seri Rama, Hikayat Pandawa Lima, Bharatayuddha, Hikayat Maharaja Ravana and others. The key point of this study was to analysed how cultural and literary influences the India epics have travel via trade activities to Kepulauan Nusantara. Besides that, Fiona E Chiong Wong and Ghulam-Sarwar Yousof (2019) written "A Visual Analysis of the Hanuman Kera Putih Puppet in Wayang Kulit Kelantan" has discussed about one of important character in both text, Hikayat Seri Rama and Hikayat Maharaja Wana, which is Hanuman (Ramayana) that been renamed as Hanuman Kera Putih. Ramayana text has been adapted into local folk oral version to perform in shadow play (wayang kulit) which used the local folklore version of Hikayat Seri Rama then the classical version of Ramayana. Hybrid character, Hanuman Kera Putih played a vital role in Kelantan shadow play. Therefore, this study will look upon Ramayana and Hikayat Seri Rama as dual different text, not as adaption text and furnish an answer to a question, whether Ramayana and Hikayat Seri Rama can be read thru the lense of just war theory.

The objective of this study had divided into two sections. First, to identify whether the scenes in Ramayana that crime leads to war, are similar to Hikayat Seri Rama (because it's an adaption version of Ramayana) or vice versa? Secondly, to read and analyse the Sita: An Illustrated Retelling of the Ramayana and Hikayat Seri Rama versi lisan based on the just war theory. 


\section{Just War Theory}

Just war theory expand from Roman and early Christian thinkers such as St. Augustine and Cicero (Balkaran and Dorn, 2012: 3). Furthermore, the just war theory has developed and provided unequivocal criteria to understand the use of force which lead to war. Just war theory by Michael Farrell has chosen to analyze the selective text; Sita: An Illustrated Retelling of the Ramayana and Hikayat Seri Rama oral version. Even though the just war theory about war has to fulfil certain conditions for it to qualify to be a just war, it can be include cause of crime that leads to war too.

This theory consist of six criteria, the first criteria is just cause. According to Michael Farrell (2013: 15), the war must be fought for a valid and good purpose. This cause provides justification for waging a war because war can cause mass destruction and other loss too. Second, last resort that before declaring war, a nation must figure out whether violence is the only solution left. Diplomatic should be prior options before a nation waged war (Michael Farrell, 2013: 16). Diplomacy should be brought to deliberation, so can prevent war loss in both sides.

Third, reasonable prospect of success. It is because of a nation wages or declares war, it must sensibly determine the probability of winning the war (Michael Farrell, 2013: 16). Even the nation has just cause criteria, if winning chances are low, then the war should not be pursued (to prevent loss to the nation). Fourth, right authority is what identifies a war from acts of domestic offensive. War can be waged and also declared only by a proper constituted authority (Michael Farrell, 2013: 16). The properly constituted authority are leaders of a nation and the government which can declare war.

Fifth, right intention need to ponder upon whether it consists of a just and beneficial goal for the outcome of the war (Michael Farrell, 2013: 17). It should scrutinize the intentions of waging a war and it must be a good intention. Six, proportionality to execute this code, means to conduct the war must be a favorable result to the end (Michael Farrell, 2013: 17). Winning the war should take consideration by nation and proximity cost is worth by outcome of the war. If the war end cost is too costly, then the war must not be fought.

This paper addresses the crime in the epic of Ramayana and Hikayat Seri Rama in order to assess the justification of the war (cause by the crime). The classic Indian society and Malay traditional society concerned with crime cause war and looked into great detail through epics by authors.

\section{Just War in Ramayana and Hikayat Seri Rama Just Cause}

First, a crime that Ravana had commit is violated Vedavati without her consent. Vedavati is a chaste woman, beautiful maiden, and she was in her tapas (meditation) towards Lord Vishnu for being his consort. At that moment, Ravana saw Vedavati in the forest and mesmerized in her beauty. Even though Ravana knows that Vedavati is a chaste woman and won't agree to his lustful demand, but Ravana still did the heinous crime (which try to force himself to Vedavati). So, Vedavati curse Ravana that she will be his reasons for death in future and burn herself down. This episode has become one of just cause that Ravana commit a crime to lead the war in future. However, this episode didn't take place in Hikayat Seri Rama oral version. This event in Ramayana described as below: 
"Later, Ravana too tried to molest Vedavati...Vedavati jumped into a fire... Vedavati swears that she will ensure the death of Ravana who tries to molest her."

(Devdutt, 2013: 120)

Second, crime that Ravana had commit is kidnapping Sita, Rama's wife to Lanka and prison her forcefully at Asoka Vanam, Lanka for one year before Rama won the war with Ravana. This event occurs when Surpanakha, Ravana's sister try to seduce Rama and Lakshmana at the forest (while being in exile for 14 years) but she fails the attempt. So, Surpanakha attack Sita (Surpanakha thought because of Sita, she fail to seduce them) and Lakshmana attack Surpanakha to protect Sita. Then, Surpanakha had sketch fatal plan by poisoning Ravana's mind with Sita's beauty. Although, Ravana has a King of Lanka who knows that abduction other man's wife is a dreadful crime and kept as a hostage is a crime cause the war. This event was documented in Ramayana as follows:

Ravana looked at her and smiled, 'Inside the line, you were someone's wife. Outside you are just a women for the taking.' Sita screamed. He grabbed her arm, tossed her over his shoulder and summoned his chariot.

(Devdutt, 2013: 133)

Meanwhile, Maharaja Dewana had commit war crime by kidnaping Tuan Puteri Sekuntum Bunga Setangkai to Pulau Kacha Puri. This event took place when Maharaja Dewana hypnotize Tuan Puteri Sekuntum Bunga Setangkai because he falls for her profound beauty. Maharaja Dewana makes dreadful act by hypnotizing Tuan Puteri Sekuntum Bunga Setangkai and kidnap her to Pulau Kacha Puri, describe as below:

Maharaja Dewana datang dari negeri Pulau Kacha Puri ka-negeri Tanjong Bunga menghendakkan tuan puteri Sa-kuntum Bunga isteri Raja Seri Rama hendak dibuat-nya isteri (Rama 1910: 67)

Furthermore, these events above showcase war crime that leads to war between Rama and Ravana and, Kera Kecil Imam Tergangga and Maharaja Dewana in Hikayat Seri Rama.

\section{Last Resort}

The use of force is normally the last resort in a just war. Rama (an avatar of Vishnu) only resulted in the use of force after he was convinced that Ravana could not stop causing trouble for the gods, sages and the people who depended on them (O'Driscol, 2018: 231; Yatin, Alias, Awang, \& Burhanud-din, 2018; Tzotzou, 2014; Omar, Rahman, Hamid, 2018). Rama displayed great patience in his quest and he did not wage unnecessary wars. He always took time in deciding his course of action. The rescue of Sita, for instance, took a great deal of patience and strategizing. Engaging in war without proper planning would have otherwise led to hurting a lot of innocent people.

The fact that Rama did not harm people who were not involved in the war justifies his war. Rama also sought alliances that enabled him to recover Sita and defeat Ravana in the long run. The use of Hanuman to spy on the whereabouts of Sita and to enter the citadel where Ravana had put Sita as a hostage is also a great display of the discipline that Rama had in the war. As a diplomacy act, Rama as sends Angada as a peace messenger to Lanka and convey Rama message which is to release 
Sita and to repent the crime that Ravana has done. However, Ravana disgrace peace messenger's message and Rama had no other choice then wage a war against Ravana. This is described as below:

"...he found his way to the garden of Ashoka trees next to the palace. He saw there a woman under a tree, no jewels on her body except her hairpin, surrounded by many rakshasa women, clearly there to guard her, but who had dozed off...So you had to be Sita. Thus it was that I found you,' said Hanuman to Sita.

“...Clearly, Ram knows more than you.' At the mention of Ram's name, there was an uncomfortable silence in the room. Ravana realized the monkey was here in Lanka on a mission, not by accident. 'Yes, I have been sent by the Ram whose wife you abducted like a thief. Unbecoming of one who calls himself brahmin, unbecoming of someone who calls himself king. Return her to her husband. Respect dharma'."

(Devdutt, 2013: 195 \& 199)

“...Ram said, 'Let us not fight like barbarians raiding a village. Let us send a messenger to the rakshasas offering to withdraw if they let my Sita go.' Angada was chosen to serve as Ram's messenger."

"Finally, Angada communicated the message: 'Ram stands outside the gates ready to attack this city with his army of monkeys. But there can be peace if you return to Ram his wife. A king should care for the welfare of his subjects first, not his pride, or lust.'... Still Ravana said, 'I do not fear you. I will kill you and your band of monkeys and your king and that Ram and that Lakshman and that traitor who calls himself my brother.'..." (Devdutt, 2013: 220 \& 221)

Mir Hassan also portrays in Hikayat Seri Rama that using force as last resort when other resources fail to bring a conclusion to the conflict. Kera Kecil Imam Tergangga shook the hills near Pulau Kacha Puri by hand as a sign of warning to Maharaja Dewana and return his mother, Tuan Puteri Sekuntum Bunga Setangkai to Seri Rama in peace. Maharaja Dewana ignore Kera Kecil Imam Tergangga warning, even he kept Tuan Puteri Sekuntum Bunga Setangkai in a castle (didn't marry her due to father-daughter relation, which Maharaja Dewana got to know after he brings Tuan Puteri Sekuntum Bunga Setangkai to Pulau Kacha Puri ). Kera Kecil Imam Tergangga needs to used force against Maharaja Dewana as described as below:

Maka titah Raja Seri Rama, "Gunung Enggil-Berenggil itu-lah tempat engkau pergi mengambur." Maka ia pun pergi-lah. Tetapi, "harap di-ampun gunong itu pun tiada tahan." (Rama, 1910: 78)

\section{Reasonable Prospect of Success}

The probability of success in the war, which is a reasonable prospect of victory also a key factor to consider in justifying a war (Balkarn \& Dorn, 2012: 11). Rama and Lakshman well trained on how to fight Ravana. The reasonable of success in the war was therefore assured. The lessons that the two princes were given versed them well with spiritual wars. Their knowledge came in handy in their war against Ravana. They were able to identify the schemes developed by Surpanakha against them such as the attempt by changing as beautiful maiden to seduce the princes. The trick that 
Ravana used capturing Sita was also anticipated by Rama and Lakshman and it was only successful due to Sita's insistence (Golden deer by Marican demon). The knowledge that the Rama had also enabled them to defeat Khara and other demons that they encounter during exile. This is described as below:

"...just when she said this she saw a deer, shining like gold. It had two heads and long antlers... "Let me catch him for you, Sita. Alive, it will make a great pet. Dead, its skin will make a lovely mat for you,' said Ram. Sita did not stop Ram. She was spellbound by the creature. She wanted to possess it. And Ram saw this in her eyes. For the first time in all these years, she wanted something. 'I will fetch it for you,'he promised,...

"Lakshman warned, 'Golden deer do not exist. This is unnatural.'”

"Then, mid-afternoon, they heard a cry: 'Save me, Lakshman. Save me, Sita. I am dying.'Sita, who had not eaten food nor sipped water since Ram's departure, became agitated. Once again they heard the voice.

'Go to him, Lakshman. There is trouble,' said Sita."

"Lakshman flinched at these words. 'Something is amiss. This is a trick. This forest is full of rakshasas who can mimic anyone's voice. I don't think Ram is in trouble..."

"But before he left, he traced a line around Sita's hut. 'This is the line of Lakshman, the lakshman-rekha. I imbue it with the power of hymns I have learned from Vasishtha and Vishwamitra. Any man who tries to cross this line will burst into flames instantly." (Devdutt, 2013: 129 \& 130)

The knowledge that Rama has is the one that enables him to overcome Ravana in the battle of Ramayana. The rescuing of Sita is also one of the instances in which the knowledge of spiritual warfare was required. Besides that, Rama has accompanied by Hanuman during the battle with Ravana. Hanuman is a symbol that represents the latent spiritual and self-strength, Thus, Hanuman was able to cross the vast ocean to reach Lanka. Finally, he met Sita, who was Ravana's prisoner in the Asoka Vanam. The success of the mission that Rama had against Ravana depended on the teachings that he had received and his success in rescuing the gods, sages and the society, in general, is due to his application of the knowledge that he had.

The magical aspect of the war made it necessary for people who wanted to stop Ravana to be well-versed with magical weapons and war strategies. Rama and Lakshman were ready to wage the war since their knowledge matched that of Ravana in the sense that it was not too little or too much. It should be noted by Hanuman meeting Sita at Asoka Vanam and later set up fire at Lanka as indicated below:

"She looked up and saw a strange sight: a silver monkey chanting the name of Ram. The monkey opened the palm of his hand and dropped something on the ground. It was a ring. Sita's eyes widened: it was Ram's ring. She looked up; the monkey came down and spoke, in a human voice: "I am Ram's messenger, Hanuman. I have been sent to find you.'..." (Devdutt, 2013: 152)

"...As the fire blazed on the tip of his tail, Hanuman broke the bonds around his arms and leapt up the ceiling and lashed his burning tail against the pillars of the 
places. As Ravana watched, the tapestries adorning his place and the columns of the courtyard began to burn. The flames spread across the walls and roofs, from the place to the roofs of houses nearby. Before long the whole city was ablaze.... The only place in Lanka that the fire did not spread to was the Asoka vanam where Sita sat, surrounded by the women and children of Lanka."

(Devdutt, 2013: 201)

In the other side, Kera Kecil Imam Tergangga has unusual strength and power (he try to catch the sun, which he was mistaken assume a red bright fruit and he escapes from the sun's heat by just fainting). So, the reasonable prospect of success was therefore assured. Kera Kecil Imam Tergangga's maternal grandfather, Raja Shah Noman has gifted him with powerful army forces and they will appear whenever Kera Kecil Imam Tergangga summon them for help. This event described as below:

Ada pun titah Raja Shah Noman, "Pergi-lah engkau ka-padang Anta-Beranta sabelah utara gunong Enggil Berenggil di-tengah-tengah hutan itu. Maka bawa-lah puntong gaharu kemenyan barus aku ini; telah sudah di-bakar, maka berchekak pinggang-lah engkau menga-dap empat penjuru alam dunia ini; panggil lashkar hulu-balang itu yang pertama Janggut, kedua Mabit, ketiga Baya Penglima Baya, keempat Bikar;... Hikayat Seri Rama (1910: 60)

\section{Right Authority}

Waging a just war involves the right authority to declare and conduct the war (Subedi, 2003: 343). In the Ramayana, the princes Rama were justified to declare war against Ravana's crime. It's because Vishnu who had decided a mortal form (Rama as a prince of Ayodha) in order to declare war and be able to fight Ravana who could only be defeated by a mortal form. Consequently, the Gods prayed to Vishnu and requested him to appear as a human being in the Ikshvaku lineage and as a prince to King Dasarata. This event occurred as Ravana, the king of Lanka did not wish for the boon that he will be killed by a human. This event is described as below:

"Brahma thought it over. He had so blessed Ravana that the latter would not be killed by devata, gandharva, yaksha or a rakshasa. He had not included a human being in this list."

"They suggested that Vishnu be born as four sons to Dashratha so that as a human being, he could destroy Ravana without violating Brahma's commitment."

(Rajendra, 2013: 12)

Ravana was guilty of oppressing the gods, sages and people, by misused his boons and powers against innocents for his greed and its considered crime and also sin. So, Vishnu wanted to put an end to this and had to act accordingly to protect the other and the entire Hindu society by extension. Stopping Ravana was inevitable and the only issues to consider was the way through which this could be done. The princes Rama were first made aware of the situation that confronted them to ensure that he only stuck to the mission of freeing the sages and people by exile to the forest with Lakshman and Sita for 14 years. The princes Rama were also made aware of the reason for the war and he is the right authority to declare war. This event was documented in Ramayana as follows; 
"In your past life, you were a gandharvi and you were told by our common father to take birth as Manthara and ensure that the eldest son of Raghu-kula is exiled into the forest where he can put an end to the rakshasa way of life"

(Devdutt, 2013: 99)

Compared to Hikayat Seri Rama regarding this matter, Mir Hassan sketches the situation when Maharaja Dewana kidnaps Tuan Puteri Sekuntum Bunga Setangkai which Seri Rama's wife and kept her as a hostage at Pulau Kacha Puri . These actions bring shame to Seri Rama. Seri Rama asks his son, Kera Kecil Imam Tergangga to wage a war against Maharaja Dewana and uphold the righteous. Seri Rama as a right authority to declare war against Maharaja Dewana for the crime commit by him. This event is described as below:

Maka Raja Seri Rama pun bertitah demikian kata-nya, "Hai anak-ku Kera Kechil Imam Tergangga, jika engkau lalu menudong kemaluan aku ini engkau aku ambil balek bawa pulang ka-negeri serta di-aku anak dari-pada dunia sampai ka-akhirat. Maka engkau mengambil bonda engkau itu jangan menchuri padan hendak-lah ambil dengan sifat laki-laki aku pinta bakarkan negeri Pulau Kacha Puri biar menjadi padang jarak padang tekukur supaya puas hati-ku."Maka "Baik-lah"kata Kera Kecil Imam Tergangga Hikayat Seri Rama (1910: 76)

\section{Right Intention}

The right intention is among the key factors that one has to consider in justifying a war. Vishnu had the purpose of promoting peace by stopping Ravana. Rama and Lakshman were also involved in a series of conflicts while in exile (Devdutt, 2013: 84). The war against Tadaka by Rama is also justified since it was a response to an attack. The intention of Rama to fight against Tadaka is caused by Tadaka's crime (murdering and also wreck the peace in the kingdom) against sages and also people. Tadaka was a man-eating monster and stopping sages from yagna which was important in protecting the people of the kingdom. The event is illustrated as follows:

"That's Tadaka, matriarch of this herd of rakshasas, stronger than all the others put together,' Vishwamitra said. 'Use the mantras that will turn your arrows into missiles imbued with the power of the sun, the moon, wind, water and fire. Shoot her dead, for she alone can force her way into the hermitage and destroy the yagna-shala.'

'But that is a women. The scriptures tell us not to hurt women,'argued Lakshman.

'Villains have no gender. Shoot!'shouted Vishwamitra."

(Devdutt, 2013: 39 \& 40)

Surpanakha, Ravana's sister had played a vital part in the kidnapping of Sita and resulted in waging a war between Rama and Ravana. Surpanakha even tries to kill Sita (which crime to harm innocent and also try to seduce married men) after failing to seduce Rama and Lakshman. Ravana commits the crime and sin by kidnapped Sita, even she justifying the need to stop him. The hurting of innocent people such as the kidnapping of Sita made it necessary for an individual to save them from Ravana's evils. Ravana has proved that he is entirely determined to cause trouble (a crime that lead to war) and he would go to any extent including hurting people who are not even concerned with his quest. The intention of Rama and Lakshman are truly justifiable unlike those of Ravana 
making the war of the princes against the demon justifiable (Subedi, 2003: 343). This was described as below:

"She first went to Ram, who she felt was taller and had wider shoulders, and said, 'Come, be my beloved, satisfy my desire.' Ram, amused by this unabashed display of desire, said, 'I am married.'

"When she approached Lakshman, he said, 'No, go away. I am not interested. I serve my brother and no other.'

"Surpanakha did not understand. Why would they turn her away? Was she not attractive? Were they not lonely? She then saw Sita seated beside Ram and surmised that perhaps with her around they desired no satisfaction elsewhere. She was the rival. She had to be exterminated. So like a beast in heat, she rushed towards Sita, determined to strike her with a rock and smash her skull. 'Stop her', shouted Ram, pulling Sita behind him."

"Then I will punish her,' said Lakshman. 'I will teach her a lesson that she will never forget.'He grabbed a knife and in one swift stroke chopped off her nose."

(Devdutt, 2013: 125 \&126)

Compared to Hikayat Seri Rama, Kera Kecil Imam Tergangga need to prove to his father, Seri Rama that he is capable to defect and safeguard his mother (the right intention), Tuan Puteri Sekuntum Bunga Setangkai and fight with Maharaja Dewana, the unrighteous king. Although, Seri Rama has outcast Kera Kecil Imam Tergangga because he born as a monkey with human characteristic. Kera Kecil Imam Tergangga still carries his duty as a son and also as a crown prince which request by Seri Rama. The incident is illustrated as follow:

"...Raja Seri Rama datang membawa isteri-nya Sa-kuntum Bunga Sa-tangkai serta dengan anak-anda Kera Kechil. Maka di-palu orang-lah segala gong gendang serunai nafiri alamat raja yang besar beroleh kesukaan. Maka Kera Kechil Imam Tergangga pun menghadap Raja Seri Rama persembahkan langgaran Maharaja Dewana..." Hikayat Seri Rama (1910: 87)

\section{Proportionality}

A just war also requires a favourable result at the end of a war which is good triumph over evil in Ramayana. The war against Ravana is justified by the fact that the evils and crimes that Ravana would cause to the people and the gods were necessary to be stopped. The benefits that the people would yield were continued seasons of peace for the gods, sages and the people. The quest by Vishnu through Rama was therefore justifiable as it was entirely for the greater good of all the members of the society.

The general society was the one that benefited from the war and there was no individualism of any kind. The war by Rama also involved the right conduct by Rama and his allies according to the principle of a just war. Rama did not engage in any conflict for his sake besides defeating Ravana for the sake of the gods, sages and people. The rescue of Sita and the gods are justifiable since they were innocent parties that were suffering due to the evils that they were not responsible for. The killing of man-eating Tadaka, Khara and Dushana was also a major relief for the people who would end up 
being a mere delicacy of the monster. So, the result of the war which is more benefits. This is described as follows:

"The war was over, Ravana was dead, Sita was liberated, Lanka had a new king..." (Devdutt, 2013: 257)

In Hikayat Seri Rama, the war against Maharaja Dewana is justified by the fact that the misdeed/ evil deed that Maharaja Dewana would cause to the people was necessary to be stopped. The benefits that Kera Kecil Imam Tergangga get is acceptance from his parents and also from people which complete his journey as a hero and also crown as a new king to Tanjung Bunga kingdom. He also transforms Kera Kecil Imam Tergangga to human form as Mambang Bongsu at the end of the story. This event described as below:

Sa-telah selesai dari-pada pekerjaan nikah itu, maka pada malam yang ketiganya, waktu tengah malam ia pun keluar-lah dari-pada sarong-nya menjadi seperti sipat manusia. Maka sarong-nya itu pun di-taroh di-balek bantal besar...Maka inang tua pun bangkit mengambil sarong-nya kera itu lalu di-bakar asap-nya menjadi kain puteh abu-nya menjadi uri...Telah sudah santap sudah menjadi manusia terlalu elok rupa parasnya gilang-gemilang kilau-kilauan tuan puteri dengan Mambang Bongsu itu, maka inang tua pun pergi-lah mengadap Raja Shah Kobad persembahkan Kera Kecil Imam Tergangga sudah menjadi manusia terlalu elok rupa paras-nya...

Rama (1910: 93 \& 94 )

\section{Findings and Conclusion}

The findings of this study revealed that the just war theory is suitable to analyze the Ramayana and Hikayat Seri Rama. The war against Ravana in Ramayana and Maharaja Dewana character in Hikayat Seri Rama is justice. There is a crime that commits by Ravana which leads to war such as missuses boon which given by god for the betterment of world but he has to enforce power against gods, sage and people, dishonoured Vedavati, kidnapping Sita and hold her as a hostage for one year at Asoka Vanam, Lanka without Sita's consent. This is because Rama as an avatar of Vishnu, had the right to wage the war against Ravana.

Analogize to Hikayat Seri Rama, Mir Hassan as a storyteller (penglipur lara) take Ramayana as an inspiration and gave local colour to Hikayat Seri Rama. The war scenario in Hikayat Seri Rama is based on Mir Hassan creativity and local wisdom to portray this text to a Malay audience. The finding shows that Ramayana's just war is based on sacred war, compared to Hikayat Seri Rama just war is more to develop a storyline and broadcast Kera Kecil Imam Tergangga as a wira in the hikayat.

Finally, it can be concluded that Hikayat Seri Rama can be compared to Ramayana through the aspect of just war theory. Even war in Hikayat Seri Rama to showcase local wisdom and creativity of the author. It is because previously just war studies mostly focus on Ramayana and Mahabharata, the two major epics from India. Moreover, Hikayat Seri Rama is an adaption text from Ramayana but as localized by Mir Hassan, which he took inspiration from the Ramayana. This paper had contributed and also act as a stepping stone for comparative study in Ramayana and Hikayat Seri Rama through the just war between two different country and culture such as India and Tanah Melayu. 
INTERNATIONAL JOURNAL OF ACADEMIC RESEARCH IN BUSINESS AND SOCIAL SCIENCES

Vol. 10, No. 1, Jan, 2020, E-ISSN: 2222-6990 C 2020 HRMARS

\section{Acknowledgement}

Article based on FRGS Grant (Ministry of Higher Education Malaysia) entitled "Pembentukan Sistem Pertahanan Melayu Nusantara Berdasarkan Karya-karya Tradisional" (203/ PHUMANITI/ 6711622) (2019-2021) lead by Dr. Mohamad Luthfi Bin Abdul Rahman.

\section{Corresponding Author}

Puganeswari D/O Balakrishnan

School of Humanities, Universiti Sains Malaysia, 11800, Pulau Pinang, Malaysia.

Email:puga_810@yahoo.com

\section{References}

Balkaran, R., \& Dorn, A. W. (2012). "Violence in the Vālmīki Rāmāyaṇa: Just War Criteria in an Ancient Indian Epic". Journal of the American Academy of Religion. Vol 80, No. 3. Page 659-690.

Pattanaik, D. (2013). Sita: A retelling of the Ramayana. India: Penguin books.

Ming, D. C. (2018). The Reworking Indian Epics in the Hands of Javanese and Malay Authors. In: Shyam Saran (Ed). Cultural and Civilisational Links Between India and Southeast Asia. Singapore: Palgrave Macmilian.

Fiona, E., Wong, C., and Yousof, G. S. (2019). "A Visual Analysis of the Hanuman Kera Putih Puppet in Wayang Kulit Kelantan". Malaysian Journal of Performing and Visual Arts. Vol 5, Page 29-43.

Roy, K. (2012). Hinduism and the Ethics of Warfare in South Asia: From Antiquity to the Present. New York: Cambridge University Press.

Maxwell, W. E. (1910). "Hikayat Seri Rama”. Journal of the Straits Branch of the Royal Asiatic Society (JSBRAS), Singapore. Bil 55. Page 1-99.

Farrell, M. (2013) Modern Just War Theory: A Guide to Research. Lanham, Maryland: Scarecrow Press, Inc.

Jagannathan, N. S. (2002). The Kamba Ramayana. New Delhi, India: Penguin Books Pvt. Ltd.

O'Driscoll, C. (2018). The Irony of Just War. Ethics \& International Affairs. Vol. 32, No. 2. Page 227236.

Puganeswari Balakrishnan \& Rahimah A. Hamid (2018). "Valmiki Ramayana: A Spiritual Hermeneutic Reading". International Journal of Academic Research in Business and Social Sciences. Vol 8, No. 10. Page 1235-1244.

Tandon, R. (2013). Valmiki Ramayana. New Delhi: Rupa Publications India Pvt. Ltd.

Reichberg, G. M. (2017). Thomas Aquinas on war and peace. United Kingdom: Cambridge University Press.

Singaravelu Sachitanantham (2004). The Ramayana Tradition in Southeast Asia. Kuala Lumpur: University of Malaya Press.

Subedi, S. P. (2003). "The concept in Hinduism of 'Just War'. Journal of Conflict and Security Law. Vol 8, No. 2. Page 339-361. 
Yatin, S. F. M., Alias, M. N., Awang, N., \& Burhanud-din, N. F. (2018). Cloud Computing: things to consider by Information Professionals (IP). International Journal of Academic Research in Progressive Education and Development, 7(3), 116-126.

Balakrishnan, P., Rahman, M. L. A., \& Harun, J. (2020). Crime Lead to War in Ramayana and Hikayat Seri Rama. International Journal of Academic Research in Business and Social Sciences, 10(1), 196-207.

Tzotzou, M. D. (2014). Designing a Set of Procedures for the Conduct of Peer Observation in the EFL Classroom: A Collaborative Training Model towards Teacher Development. Multilingual Academic Journal of Education and Social Sciences, 2(2), 15-27.

Omar, M.B., Rahman, A.B.A, Hamid, B. A. F.Z. (2018). The Association between Corporate Governance and Disclosure of Audit committee Characteristics: A Conceptual Model for the Saudi Listed Companies, International Journal of Academic Research in Accounting, Finance and Management Sciences 8 (3): 325-335. 